Article

\title{
The Gender Wage Gap in Peru: Drivers, Evolution, and Heterogeneities
}

\author{
Giannina Vaccaro ${ }^{1,2, *}$, Maria Pia Basurto ${ }^{3}$, Arlette Beltrán ${ }^{3}$, and Mariano Montoya ${ }^{3}$ \\ ${ }^{1}$ Swiss Centre of Expertise in the Social Sciences (FORS), University of Lausanne, Switzerland \\ 2 Institute of Social Sciences (ISS), University of Lausanne, Switzerland \\ ${ }^{3}$ Department of Economics, Universidad del Pacifico, Peru \\ * Corresponding author (giannina.vaccaro@unil.ch)
}

Submitted: 29 July 2021 | Accepted: 2 December 2021 | Published: 25 January 2022

\begin{abstract}
Despite the recent economic growth and gender equality improvement in educational attainment, important gender disparities remain in the Peruvian labour market. This article provides a comprehensive overview of the Peruvian gender wage gap evolution during 2007-2018 and identifies key elements that explain its patterns. First, the article shows that the raw wage gap showed an upward trend between 2007-2011, ranging from $6 \%$ to $12 \%$, and remaining around that top bound ever since. Second, using Oaxaca-Blinder decomposition we find that the unexplained wage gap has remained virtually unchanged at around $17 \%$ during the study period. Reductions in endowment differences between men and women coupled with a stagnant unexplained gap led to slightly larger raw wage gaps over time. Moreover, the stagnant unexplained gap suggests the presence of structural problems regarding social norms, gender stereotyping and potential discrimination that affects the wage gap. Third, we show that both at a national and regional level, gender wage gaps are larger within the lowest percentiles, and they mostly have a downward slope across the earnings distribution. Finally, after computing the raw and unexplained gap at the region-year level, we show that smaller regional gender gaps are associated with (a) higher GDP, (b) lower levels of domestic physical violence against women, and (c) lower percentages of women as household heads.
\end{abstract}

\section{Keywords}

gender discrimination; gender inequality; gender wage gap; Peru; regional inequality

\section{Issue}

This article is part of the issue "Recent Trends in Inequality and Exclusion in Latin America" edited by Maria Amparo Cruz Saco (Connecticut College / Universidad del Pacífico).

(C) 2022 by the author(s); licensee Cogitatio (Lisbon, Portugal). This article is licensed under a Creative Commons Attribution 4.0 International License (CC BY).

\section{Introduction}

Over the last two decades, Peru has been one of the growth leading economies in Latin America, with an annual average GDP growth of 5.3\%, largely outperforming most of its regional peers (International Monetary Fund, 2020). Moreover, during this period, women were able to achieve important human capital gains: By 2018, the proportion of women with higher education was already greater than that of men ( $12 \%$ vs. $10 \%)$, which represents a substantial improvement considering the long-lasting gender inequalities that Latin America has faced as a society. Despite these gains in human capital accumulation, there are notorious barriers that women still face in the Peruvian labour market (Barrantes \& Matos Trifu, 2019; Vargas, 2014).

Our study aims to analyse gender wage disparities in Peru between 2007 and 2018. Peruvian gender wage and employment gaps experienced a sharp decrease during the 70s and 90s (MTPE, 2006; Nopo, 2009), and in terms of the overall economic participation and opportunity index, Peru ranks 90 out of 153 countries, placing $60 \%$ among Latin American and the Caribbean countries. However, in terms of wage equality for similar work, Peru ranks 128 out of 153 countries, being one of the most unequal countries in the region (WEF, 2020, p. 285). In this article, we construct a measure of the unexplained wage gap that takes into account the notion of equal 
wage for similar work, thus building the unexplained wage gap as the difference between men and women's raw wages that cannot be explained by differences in observable human capital, sociodemographic characteristics, or occupation.

This article builds on previous work by providing a better understanding of gender inequality in Peru in four different ways. First, we update the analysis of the gender wage gaps in Peru using recent data covering 2007 to 2018. To the best of our knowledge, Ñopo (2009) was the most recent study about the evolution of the Peruvian gender wage gap and comprised a period between 1980 and 2000. We find that the raw wage gap showed an upward trend between 2007-2011, ranging from 6\% to $12 \%$, and remaining around that top bound ever since. On the other hand, the unexplained wage gap (also called "adjusted gap") has remained virtually unchanged at around $17 \%$ during the analysis period, with only minor reductions between 2011 and 2018.

Second, after having quantified the size of the gender wage gaps, we investigate the drivers of these differences. We focus on how particular variables related to human capital accumulation (e.g., education, tenure) may contribute or attenuate the observed gender wage gaps. In contrast to other work, our data also allows us to explore the role of sectoral activity and occupation on these gender gaps. Furthermore, we also account for the potential effect of non-random selection on the observed gaps.

Third, we investigate gender wage differences across the wage distribution. By employing a large cross-section panel, we can identify compositional shifts in the unexplained gap for different quantiles over time. Besides Carrillo et al. (2014) and Del Pozo Segura (2017), there is very limited evidence on how the gender gap behaves across the wage distribution. We provide evidence that the most vulnerable workers are consistently exposed to higher unexplained wage differences. This includes the ones positioned at the lowest tails of the income distribution, such as informal workers, and those least educated.

Finally, to the best of our knowledge, this is the first study that computes gender wage differentials at a Peruvian regional level. We shed light on the regional heterogeneities on the raw and unexplained gender gaps and how they have evolved over time. This is particularly relevant considering the sharp differences between Peruvian regions in terms of socioeconomic characteristics, idiosyncratic beliefs, and economic composition. We find that smaller regional gender gaps are associated with higher GDP, a higher percentage of women as household heads and lower levels of physical violence against women.

\section{Data}

This study uses individual-level data from the Peruvian National Household Survey (ENAHO) for the period between 2007 and 2018. ENAHO is a representative annual national and regional survey, conducted by the
National Institute of Statistics (INEI). This survey collects detailed individual information on education, employment, income, and expenditures, and it covers both urban and rural areas in all 25 regions. A full description of the variables used in the analysis is detailed in Table 1.

The sample of the study is restricted to individuals between 18 and 65 years of age and it excludes those who are unemployed, retired, and self-employed. Although self-employment constitutes an important part of the Peruvian labour market (about $50 \%$ of the total labour force), it was excluded from the analysis because of the highly heterogeneous types of self-employment work in Peru. The reasons behind choosing self-employment are very diverse from having an economic need, wanting to work independently, not finding a dependent job, family tradition, among others (INEI, 2019, p. 175) and thus the non-observable characteristics of people who choose self-employment are also very diverse. Therefore, from an estimation point of view, including these types of workers would require us to model selection into selfemployment that is beyond the scope of this article. Finally, for each year, we trim individuals lying in the first or last percentile of the wage distribution to avoid conclusions being distorted by outliers. The total pooled sample consists of 250,000 observations.

Table 2 displays summary statistics in the initial and last study periods of our analysis. We find persistent and significant gender differences in hourly wages and educational attainment between 2007 and 2018. Men have higher wages than women even when controlling for hours worked. Both of them have accumulated more years of education over time; nonetheless, as in other countries, working women exhibit more years of education compared to men. In terms of firm size, female and male representation is very similar across the board; nevertheless, a higher percentage of women work in bigger firms, while a higher percentage of men in smaller ones (see, for example, participation differences within the 1-5 and 51-500+ firms). Finally, the prevalence of informal work is higher among men than women in our sample due to the exclusion of self-employed workers from the study. A characteristic of self-employed work is that it is more prevalent among men than women and is mainly informal work.

\section{Methodology}

\subsection{Base Estimations}

To understand which factors drive the gender wage differentials, we employ the Oaxaca (1973) and Blinder (1973) decomposition (O-B) method. We follow the extension of O-B proposed by Fortin (2008), which estimates a Mincerian wage equation for men $(m)$ and women $(f)$ separately. The form of the regressions is given by the following equation:

$$
w_{g}^{t}=\beta_{g}^{t} X_{g}^{t}+\varepsilon_{g}^{t} \cdots
$$


Table 1. Variables description.

\begin{tabular}{|c|c|}
\hline Variable & Description \\
\hline Log of hourly wage & Natural logarithm of main occupation hourly wage \\
\hline Sex & Dummy that takes the value of 1 if the person is female, 0 otherwise \\
\hline Age & Age in years \\
\hline Tenure & Years of tenure in the current main occupation \\
\hline Urban & Dummy that takes the value of 1 if the person lives in an urban area, 0 otherwise \\
\hline Public Sector & Dummy that takes the value of 1 if the person works in the Public Sector, 0 otherwise \\
\hline Informal & Dummy that takes the value of 1 if the person is an informal worker, 0 otherwise \\
\hline Years of schooling & Number of years of education \\
\hline Household head & $\begin{array}{l}\text { Dummy that takes the value of } 1 \text { if the person refers in the survey as the household head, } \\
0 \text { otherwise }\end{array}$ \\
\hline Indigenous mother tongue & $\begin{array}{l}\text { Dummy that takes the value of } 1 \text { if the person's mother tongue is referred to as Quechua, } \\
\text { Aymara, or Amazonian native, } 0 \text { otherwise. }\end{array}$ \\
\hline \multicolumn{2}{|l|}{ Categorical variables } \\
\hline Size of the firm & 5 categories in terms of number of workers $(1-20 ; 21-50 ; 51-100 ; 101-500 ; 500+)$ \\
\hline Region & Geopolitical regions: 25 categories \\
\hline Industry & Economic sector of the worker's firm: 18 categories \\
\hline Occupation & $\begin{array}{l}\text { Main occupation of the worker within the firm: } 436 \text { categories. We employ the National } \\
\text { Occupation Classification provided by the INEI (2016). }\end{array}$ \\
\hline
\end{tabular}

Notes: Hourly wage includes in-kind payments and bonuses and is constructed using reported hours worked; workers are defined as informal if they are not covered by the social security system or if their employer is not registered in the National Tributary System; size of the firm, region, industry, and occupation are included in the analysis as a set of dummies, one per variable category.

Here, $w_{g}^{t}$ is the log hourly wage and $X_{g}^{t}$ constitutes a vector of observable characteristics (listed in Table 1). This vector also includes the occupation and industry dummies. The error term is given by $\varepsilon_{g}^{t}$. Finally, subscript $t$ represents the year where the observation is collected and superscript $g$ defines gender group $(m, f)$ in which the estimation is evaluated.

Considering this specification, the O-B decomposition for year $t$ is given by:

$$
\bar{w}_{m}^{t}-\bar{w}_{f}^{t}=\hat{\beta}_{m}^{t}\left(\bar{X}_{m}^{t}-\bar{X}_{f}^{t}\right)+\bar{X}_{f}^{t^{\prime}}\left(\hat{\beta}_{m}^{t}-\hat{\beta}_{f}^{t}\right) \ldots
$$

The difference in the left-hand side refers to the observable mean wage gap between men and women. The first term on the right-hand side of equation 2 accounts for observable differences in endowments (also known as "quantity effect"), while the second term of the righthand side is attributable to differential returns to those endowments (also known as "price effect").

\subsection{Machado-Mata Quantile Decomposition}

Although average gender wage gaps provide a broad overview of the gender inequality in the market, significant heterogeneities across the wage distribution could be present (Albrecht et al., 2009; Badel \& Peña, 2010; Christofides et al., 2013). This applies both to observable raw and unexplained wage gaps. We use the Machado and Mata (2005) approach (MM) which estimates Mincerian equations for each quantile $(\theta)$, con- ditional on the set of control variables. These quantile regressions are estimated individually for men and women, producing vectors $\hat{\beta}_{m, \theta}$ and $\hat{\beta}_{f, \theta}$ for each quantile $\theta$, respectively.

The key idea of MM is based on estimating two counterfactual densities to decompose the observed wage gap. The first counterfactual density is formed by the female log wage density that would prevail if women retained their characteristics but were paid according to prices derived from the male sample regression. The second counterfactual is given by the female log wage density that would prevail if women were endowed with men's observable characteristics but were paid according to prices derived from the female sample regression.

Analogous to the O-B approach, we could express the MM decomposition (evaluated at the quantile $\theta$ ) with simplified two-alternative counterfactual distributions:

$$
\bar{w}_{m, \theta}^{t}-\bar{w}_{f, \theta}^{t}=\hat{\beta}_{m, \theta}^{t}\left(\bar{X}_{m}^{t}-\bar{X}_{f}^{t}\right)+\bar{X}_{f}^{t^{\prime}}\left(\hat{\beta}_{m, \theta}^{t}-\hat{\beta}_{f, \theta}^{t}\right) \ldots
$$

In addition, we use the Chernozhukov et al. (2013) extension to compute asymptotic standard errors.

\section{Results}

\subsection{Aggregate Results}

Figure 1 graphs the evolution of the raw, unexplained, and explained gender wage gap between 2007 and 2018. This figure shows that during this period, male raw 
Table 2. Descriptive statistics.

\begin{tabular}{|c|c|c|c|c|c|c|}
\hline & \multicolumn{3}{|c|}{2007} & \multicolumn{3}{|c|}{2018} \\
\hline & Mean (M) & Mean (F) & Diff. (M-F) & Mean (M) & Mean (F) & Diff. (M-F) \\
\hline Ln (hourly wage) & $\begin{array}{c}1.64 \\
(0.01)\end{array}$ & $\begin{array}{c}1.52 \\
(0.01)\end{array}$ & $\begin{array}{l}0.11^{* * *} \\
(0.02)\end{array}$ & $\begin{array}{c}1.99 \\
(0.01)\end{array}$ & $\begin{array}{c}1.88 \\
(0.01)\end{array}$ & $\begin{array}{l}0.11^{* * *} \\
(0.01)\end{array}$ \\
\hline Age & $\begin{array}{l}36.10 \\
(0.16)\end{array}$ & $\begin{array}{l}35.45 \\
(0.21)\end{array}$ & $\begin{array}{c}0.65^{* *} \\
(0.26)\end{array}$ & $\begin{array}{l}37.73 \\
(0.15)\end{array}$ & $\begin{array}{c}36.82 \\
(0.18)\end{array}$ & $\begin{array}{l}0.91^{* * *} \\
(0.23)\end{array}$ \\
\hline \multicolumn{7}{|l|}{ Education } \\
\hline Primary & $\begin{array}{c}1.23 \\
(0.01)\end{array}$ & $\begin{array}{c}1.16 \\
(0.02)\end{array}$ & $\begin{array}{l}0.06 * * * \\
(0.02)\end{array}$ & $\begin{array}{c}1.92 \\
(0.01)\end{array}$ & $\begin{array}{c}1.81 \\
(0.01)\end{array}$ & $\begin{array}{l}0.11^{* * *} \\
(0.01)\end{array}$ \\
\hline Secondary & $\begin{array}{l}35.17 \\
(0.16)\end{array}$ & $\begin{array}{l}34.19 \\
(0.21)\end{array}$ & $\begin{array}{l}0.97^{* * *} \\
(0.26)\end{array}$ & $\begin{array}{l}37.61 \\
(0.15)\end{array}$ & $\begin{array}{l}36.65 \\
(0.18)\end{array}$ & $\begin{array}{l}0.95^{* * *} \\
(0.23)\end{array}$ \\
\hline Tertiary & $\begin{array}{c}1.23 \\
(0.01)\end{array}$ & $\begin{array}{c}1.16 \\
(0.02)\end{array}$ & $\begin{array}{l}0.06 * * * \\
(0.02)\end{array}$ & $\begin{array}{c}1.92 \\
(0.01)\end{array}$ & $\begin{array}{c}1.81 \\
(0.01)\end{array}$ & $\begin{array}{l}0.11^{* * *} \\
(0.01)\end{array}$ \\
\hline Years of schooling & $\begin{array}{l}10.85 \\
(0.05)\end{array}$ & $\begin{array}{l}11.90 \\
(0.08)\end{array}$ & $\begin{array}{l}-1.06^{* * *} \\
(0.09)\end{array}$ & $\begin{array}{l}11.39 \\
(0.04)\end{array}$ & $\begin{array}{l}12.03 \\
(0.06)\end{array}$ & $\begin{array}{l}-0.64^{* * *} \\
(0.07)\end{array}$ \\
\hline Children number & $\begin{array}{c}2.16 \\
(0.02)\end{array}$ & $\begin{array}{c}2.15 \\
(0.03)\end{array}$ & $\begin{array}{c}0.02 \\
(0.03)\end{array}$ & $\begin{array}{c}1.88 \\
(0.02)\end{array}$ & $\begin{array}{c}1.85 \\
(0.02)\end{array}$ & $\begin{array}{c}0.03 \\
(0.02)\end{array}$ \\
\hline Married & $\begin{array}{c}0.59 \\
(0.01)\end{array}$ & $\begin{array}{c}0.44 \\
(0.01)\end{array}$ & $\begin{array}{l}0.15^{* * * *} \\
(0.01)\end{array}$ & $\begin{array}{c}0.57 \\
(0.01)\end{array}$ & $\begin{array}{c}0.42 \\
(0.01)\end{array}$ & $\begin{array}{l}0.14^{* * *} \\
(0.01)\end{array}$ \\
\hline Living in urban area & $\begin{array}{c}0.13 \\
(0.00)\end{array}$ & $\begin{array}{c}0.08 \\
(0.00)\end{array}$ & $\begin{array}{l}0.05^{* * *} \\
(0.00)\end{array}$ & $\begin{array}{c}0.10 \\
(0.00)\end{array}$ & $\begin{array}{c}0.07 \\
(0.00)\end{array}$ & $\begin{array}{l}0.03^{* * *} \\
(0.00)\end{array}$ \\
\hline Public sector worker & $\begin{array}{c}0.16 \\
(0.00)\end{array}$ & $\begin{array}{c}0.27 \\
(0.01)\end{array}$ & $\begin{array}{l}-0.11^{* * *} \\
(0.01)\end{array}$ & $\begin{array}{c}0.15 \\
(0.00)\end{array}$ & $\begin{array}{c}0.24 \\
(0.01)\end{array}$ & $\begin{array}{l}-0.09 * * * \\
(0.01)\end{array}$ \\
\hline Tenure (years) & $\begin{array}{c}4.61 \\
(0.10)\end{array}$ & $\begin{array}{c}4.86 \\
(0.14)\end{array}$ & $\begin{array}{l}-0.25 \\
(0.17)\end{array}$ & $\begin{array}{c}5.29 \\
(0.09)\end{array}$ & $\begin{array}{c}4.85 \\
(0.11)\end{array}$ & $\begin{array}{l}0.44^{* * *} \\
(0.15)\end{array}$ \\
\hline \multicolumn{7}{|l|}{ Firm size } \\
\hline 1-5 workers & $\begin{array}{c}0.27 \\
(0.01)\end{array}$ & $\begin{array}{c}0.25 \\
(0.01)\end{array}$ & $\begin{array}{c}0.02 * * \\
(0.01)\end{array}$ & $\begin{array}{c}0.30 \\
(0.01)\end{array}$ & $\begin{array}{c}0.28 \\
(0.01)\end{array}$ & $\begin{array}{l}0.02 * * \\
(0.01)\end{array}$ \\
\hline 6-10 workers & $\begin{array}{c}0.30 \\
(0.01)\end{array}$ & $\begin{array}{c}0.25 \\
(0.01)\end{array}$ & $\begin{array}{l}0.05^{* * *} \\
(0.01)\end{array}$ & $\begin{array}{c}0.30 \\
(0.01)\end{array}$ & $\begin{array}{c}0.29 \\
(0.01)\end{array}$ & $\begin{array}{l}0.02 * * \\
(0.01)\end{array}$ \\
\hline $11-50$ workers & $\begin{array}{c}0.14 \\
(0.00)\end{array}$ & $\begin{array}{c}0.12 \\
(0.01)\end{array}$ & $\begin{array}{l}0.02 * * * \\
(0.01)\end{array}$ & $\begin{array}{c}0.11 \\
(0.00)\end{array}$ & $\begin{array}{c}0.11 \\
(0.00)\end{array}$ & $\begin{array}{c}0.01 \\
(0.01)\end{array}$ \\
\hline 51-500 workers & $\begin{array}{c}0.17 \\
(0.00)\end{array}$ & $\begin{array}{c}0.17 \\
(0.01)\end{array}$ & $\begin{array}{c}-0.00 \\
(0.01)\end{array}$ & $\begin{array}{c}0.17 \\
(0.00)\end{array}$ & $\begin{array}{c}0.15 \\
(0.01)\end{array}$ & $\begin{array}{c}0.01 \\
(0.01)\end{array}$ \\
\hline Informal worker & $\begin{array}{c}0.40 \\
(0.01)\end{array}$ & $\begin{array}{c}0.46 \\
(0.01)\end{array}$ & $\begin{array}{l}-0.07^{* * *} \\
(0.01)\end{array}$ & $\begin{array}{c}0.42 \\
(0.01)\end{array}$ & $\begin{array}{c}0.45 \\
(0.01)\end{array}$ & $\begin{array}{l}-0.04 * * * \\
(0.01)\end{array}$ \\
\hline Observations & 9,437 & 4,737 & & 14,194 & 9,283 & \\
\hline
\end{tabular}

Notes: This table uses ENAHO sampling weights; data on wages is originally expressed in monthly current Peruvian soles (PEN); we divide it by the number of hours worked in the main occupation and use the exchange rate PEN to USD (on each survey year) to express hourly wage in USD; standard errors in parenthesis; ${ }^{*} p<0.1 ;{ }^{* *} p<0.05 ; * * * p<0.01$.

average wages were about $10 \%$ higher than those of females. From 2007 to 2011, the raw gender wage gap was slightly lower (about 8\%) but increasing. From 2012 to 2018 , the raw gap stabilised at about $10 \%$. During this period, the unexplained wage gap was steady at around $17 \%$, with only a minor decrease between 2010 and 2012. In contrast to previous studies, our results show a substantive smaller Peruvian unexplained wage gap. For example, Ñopo (2009) found an unexplained gender wage gap of $28 \%$ for the period between 1986 and 2000 . Despite the possibility of these results not being completely comparable with ours because we exclude independent workers-for which prior studies have found the gap been larger (Beltrán et al., 2021)-and Ñopo (2009) employs a matching-based technique, our numbers align with similar trends regarding the evolution of gender wage gaps in the Latin American region (Atal et al., 2009; Boraz \& Robano, 2010). 


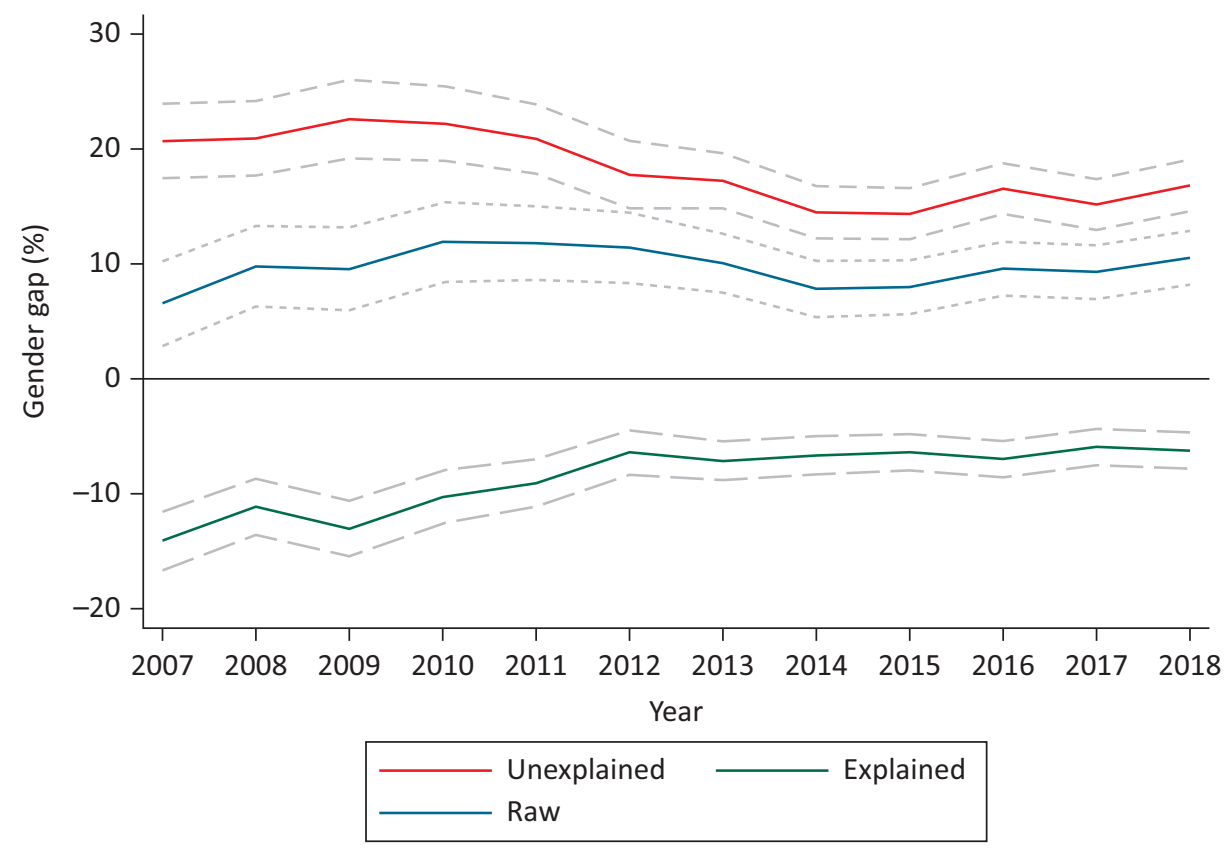

Figure 1. Wage gap decomposition. Notes: Raw gender wage gap is measured as $\ln ($ wage men)-In(wage women); solid lines refer to point estimates; dashed lines denote $95 \%$ confidence intervals.

Table 3 reports the estimated results from the O-B decomposition performed for the years 2007, 2011 and 2018. The first two rows show the mean raw hourly wage for men and women, respectively. Explained and unexplained gender wage gaps are observed in the fifth and eighth row, respectively. The contribution of education, tenure, age, activity sector, and occupation to each gender wage gap are also shown in this table. Although other controls are included (detailed in table note), we only report the contribution of variables that explain most of the size of the wage gaps.

On average, between 2007 and 2018, the unexplained wage gap was around $17 \%$. This gap could be interpreted as men, with similar human capital and sociodemographic characteristics, earning $17 \%$ more than their female peers. On the other hand, the explained gender wage gap ranges between $-15 \%$ and $-6 \%$. The negative sign of this gap can be interpreted as the attenuation effect that control variables included in the decomposition have on the raw wage gap, therefore, pointing towards employed women having better working characteristics than employed men. Furthermore, Figure 1 and Table 3 show that the unexplained wage gap has slightly reduced between 2007 and 2018 (approx. -4 p.p.), while the explained gap shrunk by about 9 pp (from $-15 \%$ to $-6 \%$ ). This suggests that the endowment difference between men and women (i.e., in terms of education, experience, tenure, and other controls used in the regression) reduced during this period, and therefore women in the Peruvian labour market are now more similar to men in terms of human capital and socio-demographic characteristics. Less attenuation effect through the explained component coupled with a stagnant unexplained gap-which is plausible consid- ering the challenge in changing idiosyncratic beliefscould have led to slightly larger raw wage gaps over time. These results are consistent with previous studies that have focused on the trend of gender wage gaps, such as González et al. (2005) and Shi et al. (2011), which also found smaller attenuation effects over time through the explained component, indicating that the gap between male and female human capital and employment characteristics was narrowing.

We find that for every reported year, education explains between 3 to 5 (negative) percentage points of the explained component, pointing towards a better education endowment in working women. Conversely, we find that, as shown in the literature, occupations and industries explain the observed gender gap (between +3 p.p. and +5 p.p.), confirming that men are consistently allocated to more profitable industries than women. Interestingly, as suggested by Neumark and Vaccaro (2020), once we account for the working sector, there are no effects through occupation composition. While the unexplained gender wage gap is always positive and statistically significant, both education and tenure contribute negatively to the unexplained component, attenuating the overall gap. As expected, most of the variables that size the unexplained component are in the constant term. This suggests that unexplained wage differentials operate mainly through non-observable characteristics, such as cultural practices in the firm, personal skills, and potentially gender discrimination.

Acknowledging that our decompositions do not account for endogenous labour participation decisions, we use a Heckman (1979) correction model into our O-B decomposition. We use standard instrumental variables used in similar literature: children under 6 years, children 
Table 3. Oaxaca-Blinder decomposition.

\begin{tabular}{|c|c|c|c|}
\hline & 2007 & 2011 & 2018 \\
\hline (1) Mean: Ln(hourly wage) for men & $\begin{array}{c}1.23 \\
(0.01)\end{array}$ & $\begin{array}{c}1.58 \\
(0.01)\end{array}$ & $\begin{array}{c}1.92 \\
(0.01)\end{array}$ \\
\hline (2) Mean: Ln(hourly wage) for female & $\begin{array}{c}1.16 \\
(0.02)\end{array}$ & $\begin{array}{c}1.46 \\
(0.01)\end{array}$ & $\begin{array}{c}1.81 \\
(0.01)\end{array}$ \\
\hline Mean $[(1)-(2)]$ & $\begin{array}{c}0.06 \\
(0.02)\end{array}$ & $\begin{array}{c}0.12 \\
(0.02)\end{array}$ & $\begin{array}{c}0.11 \\
(0.01)\end{array}$ \\
\hline Explained component & $\begin{array}{l}-0.15^{* * *} \\
(0.01)\end{array}$ & $\begin{array}{l}-0.09 * * * \\
(0.01)\end{array}$ & $\begin{array}{l}-0.06 * * * \\
(0.01)\end{array}$ \\
\hline Education & $\begin{array}{l}-0.05^{* * *} \\
(0.00)\end{array}$ & $\begin{array}{l}-0.04^{* * *} \\
(0.00)\end{array}$ & $\begin{array}{l}-0.03^{* * *} \\
(0.00)\end{array}$ \\
\hline Tenure & $\begin{array}{c}-0.00 * \\
(0.00)\end{array}$ & $\begin{array}{l}-0.00 \\
(0.00)\end{array}$ & $\begin{array}{l}0.00 * * * \\
(0.00)\end{array}$ \\
\hline Age & $\begin{array}{c}0.00 \\
(0.00)\end{array}$ & $\begin{array}{l}-0.00 \\
(0.00)\end{array}$ & $\begin{array}{l}-0.00 \\
(0.00)\end{array}$ \\
\hline Industry & $\begin{array}{l}0.03^{* * *} \\
(0.01)\end{array}$ & $\begin{array}{l}0.05^{* * *} \\
(0.01)\end{array}$ & $\begin{array}{l}0.04 * * * \\
(0.01)\end{array}$ \\
\hline Occupation & $\begin{array}{l}-0.01 \\
(0.01)\end{array}$ & $\begin{array}{l}-0.00 \\
(0.01)\end{array}$ & $\begin{array}{l}-0.00 \\
(0.00)\end{array}$ \\
\hline Unexplained component & $\begin{array}{l}0.21^{* * *} \\
(0.02)\end{array}$ & $\begin{array}{l}0.21^{* * *} \\
(0.02)\end{array}$ & $\begin{array}{l}0.17^{* * *} \\
(0.01)\end{array}$ \\
\hline Education & $\begin{array}{l}-0.18^{* * *} \\
(0.06)\end{array}$ & $\begin{array}{l}-0.17^{* * *} \\
(0.06)\end{array}$ & $\begin{array}{l}-0.13^{* * *} \\
(0.04)\end{array}$ \\
\hline Tenure & $\begin{array}{l}-0.06^{* * *} \\
(0.01)\end{array}$ & $\begin{array}{l}-0.02 * * \\
(0.01)\end{array}$ & $\begin{array}{l}-0.03 * * * \\
(0.01)\end{array}$ \\
\hline Age & $\begin{array}{l}-0.24 \\
(0.15)\end{array}$ & $\begin{array}{c}0.03 \\
(0.14)\end{array}$ & $\begin{array}{c}0.16 \\
(0.11)\end{array}$ \\
\hline Industry & $\begin{array}{l}-0.02 \\
(0.04)\end{array}$ & $\begin{array}{l}-0.02 \\
(0.04)\end{array}$ & $\begin{array}{l}-0.03 \\
(0.03)\end{array}$ \\
\hline Occupation & $\begin{array}{c}0.01 \\
(0.02)\end{array}$ & $\begin{array}{l}-0.03 \\
(0.02)\end{array}$ & $\begin{array}{l}-0.06 * * * \\
(0.01)\end{array}$ \\
\hline Constant & $\begin{array}{l}0.801 * * * \\
(0.201)\end{array}$ & $\begin{array}{c}0.30 \\
(0.199)\end{array}$ & $\begin{array}{c}0.38 * * * \\
(0.146)\end{array}$ \\
\hline Total obs. & 14,173 & 15,893 & 23,477 \\
\hline
\end{tabular}

Notes: All decompositions include controls such as education, native tongue, age, tenure, private sector and firm size, occupation, economic activity, and regional fixed effects; the explained and unexplained components are read as percentage points contributions to the raw wage gap; robust standard errors in parenthesis; ${ }^{* *} p<0.01, * * p<0.05, * p<0.10$.

between six and 17 years of age, marital status, other household member's income, and head of household (Albrecht et al., 2009; Blau \& Beller, 1988; Piazzalunga \& Di Tommaso, 2019). After correcting for the participation decision, we find two main results regarding the gender gap. On the one hand, the raw wage gap increased from 7\% to $22 \%$ between 2007 and 2018 in comparison to $6 \%$ to $12 \%$ when we do not correct for self-selection, almost doubling its size. We refer to this gap in Table 4 as the adjusted raw wage gap. To provide a graphic overview of the gender wage differences adjusted by the Heckman correction, Figure 2 plots in Panel A the raw wage gap using estimations from the baseline model, and Panel B using the Heckman-corrected estimations. This evidence suggests the presence of a positive sample selection effect: More educated and experienced women are those who mainly decide to participate in the labour market. Otherwise, if there were no participation gaps, the raw gap observed would be roughly twice as large as the current one. The direction of this correction is well documented. Similar results have been found for countries such as Colombia, Mexico, the UK, and the Netherlands (Albrecht et al., 2009; Badel \& Peña, 2010; Chzhen \& Mumford, 2011). On the other hand, evidence 
Table 4. Heckman-adjusted Oaxaca-Blinder decomposition.

\begin{tabular}{|c|c|c|c|}
\hline & 2007 & 2011 & 2018 \\
\hline (1) Mean: Ln(hourly wage) for men & 1.24 & 1.65 & 1.98 \\
\hline (2) Mean: Ln(hourly wage) for female & 1.17 & 1.41 & 1.76 \\
\hline Adjusted raw gap $[(1)-(2)]$ & 0.07 & 0.24 & 0.22 \\
\hline Explained component & $\begin{array}{l}-0.09 * * * \\
(0.02)\end{array}$ & $\begin{array}{l}-0.05^{* * *} \\
(0.02)\end{array}$ & $\begin{array}{c}-0.02 * * * \\
(0.01)\end{array}$ \\
\hline Education & $\begin{array}{l}-0.05^{* * *} \\
(0.00)\end{array}$ & $\begin{array}{l}-0.04^{* * *} \\
(0.00)\end{array}$ & $\begin{array}{l}-0.03^{* * *} \\
(0.00)\end{array}$ \\
\hline Tenure & $\begin{array}{c}-0.00 * \\
(0.00)\end{array}$ & $\begin{array}{c}-0.00 * \\
(0.00)\end{array}$ & $\begin{array}{c}0.00 * \\
(0.00)\end{array}$ \\
\hline Unexplained component & $\begin{array}{l}0.16^{* * *} \\
(0.02)\end{array}$ & $\begin{array}{l}0.17^{* * * *} \\
(0.02)\end{array}$ & $\begin{array}{l}0.13^{* * *} \\
(0.02)\end{array}$ \\
\hline Education & $\begin{array}{l}-0.17^{* * *} \\
(0.06)\end{array}$ & $\begin{array}{l}-0.16^{* * *} \\
(0.07)\end{array}$ & $\begin{array}{c}-0.15^{* * *} \\
(0.05)\end{array}$ \\
\hline Tenure & $\begin{array}{l}-0.06^{* * *} \\
(0.01)\end{array}$ & $\begin{array}{l}-0.02 * * * \\
(0.01)\end{array}$ & $\begin{array}{l}-0.03^{* * *} \\
(0.01)\end{array}$ \\
\hline III. Sample selection & $\begin{array}{l}-0.01 \\
(0.07)\end{array}$ & $\begin{array}{l}-0.12 \\
(0.08)\end{array}$ & $\begin{array}{l}-0.12 \\
(0.04)\end{array}$ \\
\hline Total obs. & 14,173 & 15,893 & 23,477 \\
\hline R2: male selection eq. & 0.13 & 0.13 & 0.15 \\
\hline R2: female selection eq. & 0.22 & 0.19 & 0.23 \\
\hline
\end{tabular}

Notes: All decompositions include controls such as education, native tongue, age, tenure, private sector and firm size, occupation, economic activity, and regional fixed effects; the explained and unexplained components are read as percentage point contributions to the raw wage gap; robust standard errors in parenthesis; ${ }^{* *} p<0.01,{ }^{* *} p<0.05,{ }^{*} p<0.10$.

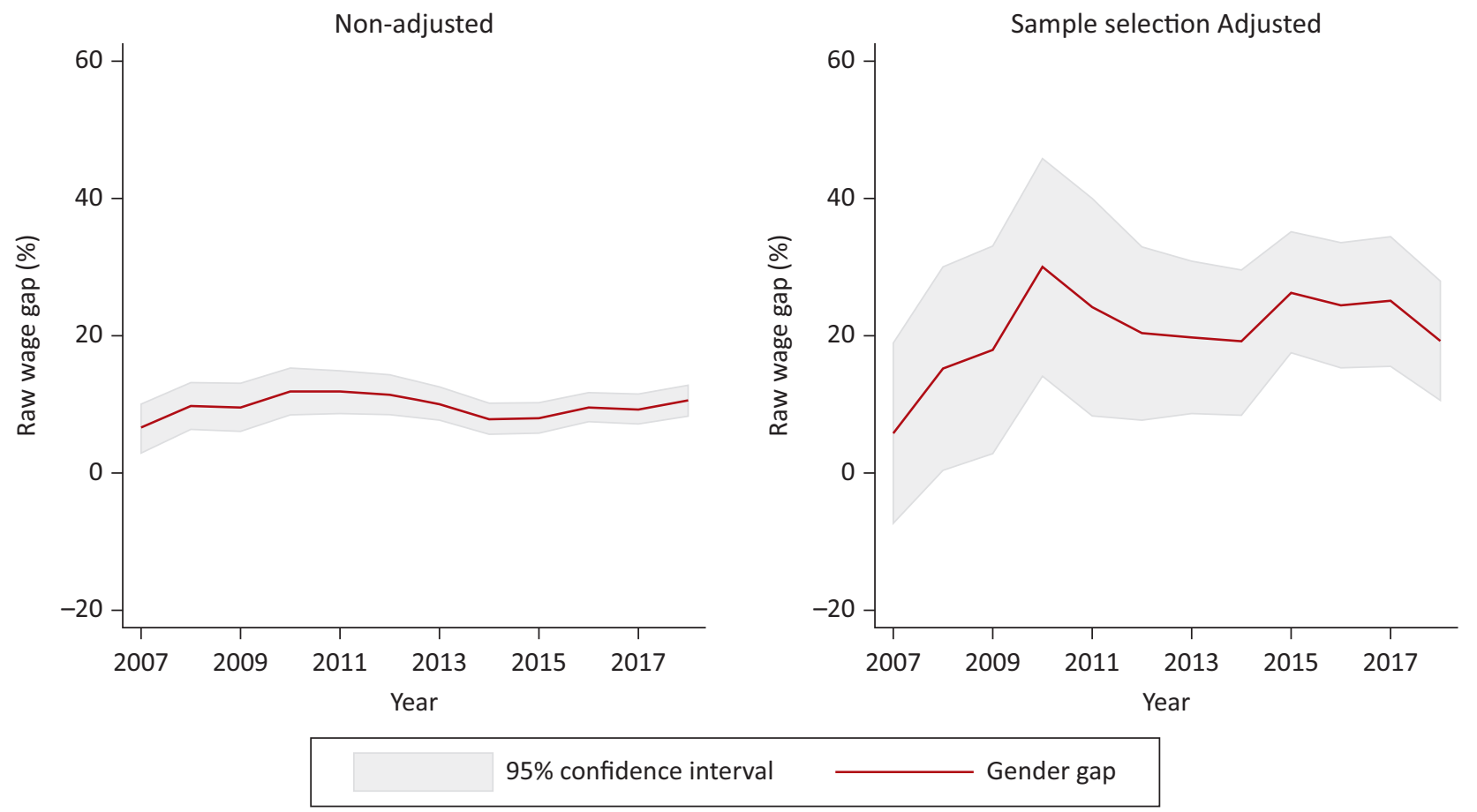

Figure 2. Raw wage gap vs. raw wage adjusted by sample selection. Notes: The dependent variable is measured as the In(hourly wage) in the main occupation; first-step Heckman estimations include as instruments: number of children under six years of age, children between six and 17 years of age, marital status, other household member's income, and head of household. 
shows that the explained and unexplained wage gaps do not change much by correcting for endogenous selection into the labour force.

\subsection{Gender Wage Gaps Across Different Subgroups}

To identify key differences that might drive heterogeneous gender wage gaps in Peru, we analyse four main population subgroups: (a) educational attainment, (b) age (as a proxy of potential experience), (c) private vs. public sector, and (d) formal vs. informal employment. We concentrate on the analysis of unexplained wage differences across these categories. Figure 3 plots the results. Four key findings are worth highlighting.

First, we show that, in Peru, the unexplained gender wage gap is consistently higher among people with the lowest level of educational attainment. This finding is aligned with international evidence, largely documented in the literature (Blau \& Beller, 1988; Hughes $\&$ Maurer-Fazio, 2002). The increase of educational credentials acts as a screening mechanism, attenuating the arbitrary components attributed to discrimination practices. Second, there are not many unexplained gender wage gap differences across people with age groups. As shown for the average population, the unexplained wage gap for each cohort has remained stable at about $15 \%$. The only age group that consistently has a lower unexplained wage gap is the older group (43 and older), this result may be a reflection of differences in children's ages among the first two groups in comparison to the latter being that younger children (especially under five) demand more care. Third, the unexplained wage gap is persistently higher in the private than in the public sector ( $17 \%$ vs. $9 \%$, respectively, for the whole period). Studies argue that this situation occurs because the public sector usually has more accountability measures and transparency labour rules that allow them to implement equal opportunity and anti-discrimination policies (Antón \& Muñoz de Bustillo, 2015). Fourth, besides more women working in the informal sector, the unexplained gender wage gap against female workers is also more pronounced (22\%). In summary, we show that women in greater vulnerability conditions (less educated and informal) have higher unexplained wage gaps than other groups, reflecting a greater disparity in terms of wage gap.
Panel A: Education level

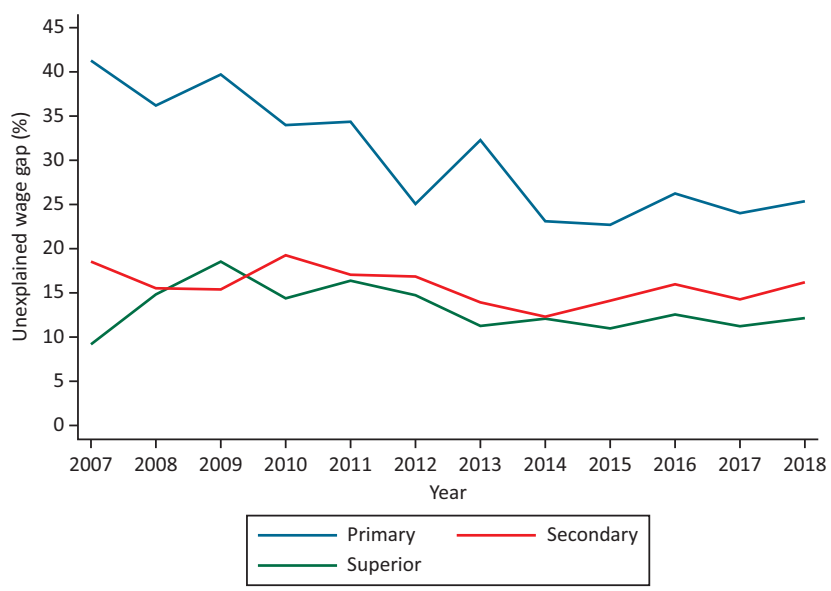

Panel C: Sector (public, private)

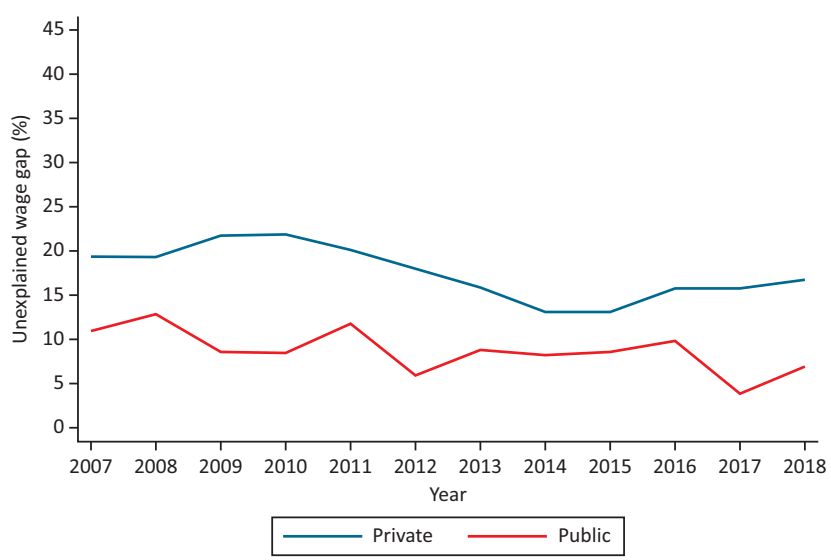

Panel B: Age cohort

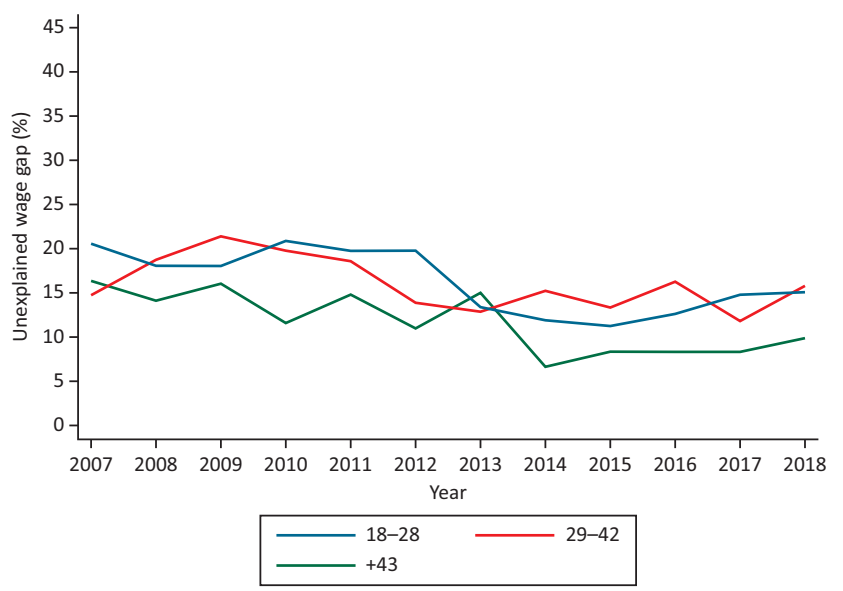

Panel D: Formality

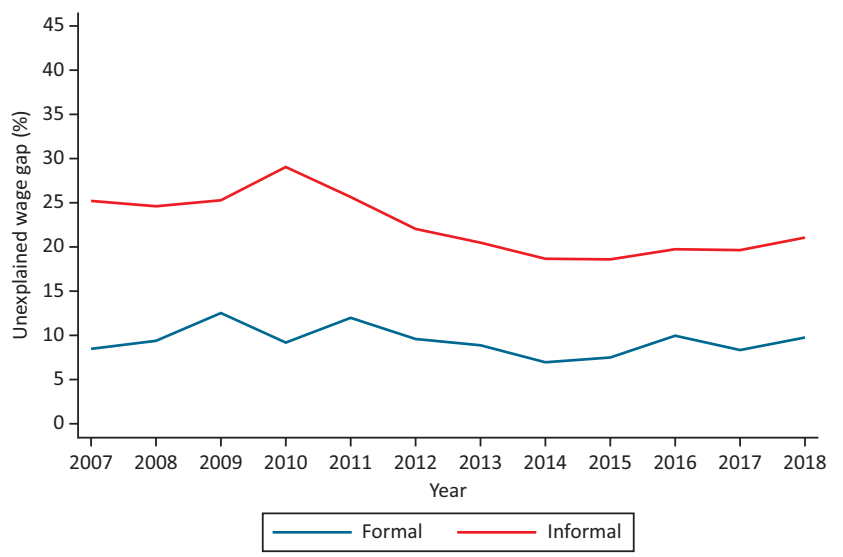

Figure 3. Unexplained wage gap across subgroups. Notes: All decompositions include controls such as education, native tongue, age, tenure, private sector and firm size, occupation, economic activity, and regional fixed effects. 


\subsection{Quantile Decomposition Results}

Table 5 reports the quantile decomposition results using $\mathrm{MM}$ at five specific percentiles $(10,25,50,75$, and 90) for three referential years $(2007,2011$, and 2018). In line with previous research (Carrillo et al., 2014; Del Pozo Segura, 2017; Nopo, 2009), we find that both gender wage gaps are considerably larger at the lowest percentiles for the evaluated period. When looking at changes over time, we find that the unexplained wage gap has reduced the most among the two lowest quantiles (around $9 \mathrm{pp}$ ). This result is consistent with the analysis done for informal and less-educated workers in Figure 3, where the unexplained gap also decreased more among the most vulnerable groups. The greater reduction of the unexplained gap among the lowest quantiles may be associated with different factors. First, it could be driven by a greater increase in endowments among these groups; for example, more human capital that can explain a larger proportion of the observed wage, thus leaving a smaller portion to the unexplained component. Second, it could be related to an increase in the returns to endowments for women. Unfortunately, our methodology does not provide a direct way of testing these drivers.

\subsection{Regional Gender Wage Differences}

Peru has been historically a very heterogeneous country in terms of regional development and socio-economic conditions. Authors such as Seminario et al. (2019) and Castillo (2020) have shown evidence of large heterogeneities in income evolution across regions. While our study does not aim to point out any causal evidence about regional heterogeneities, descriptive evi- dence about gender wage differences, between and within regions, can help to identify key features that might affect regional disparities in terms of the gender wage gap. In this section, we present the average raw and unexplained wage gaps for 25 geopolitical regions, grouped into 8 macro-regions: Northern Coast, Centre Coast, Southern Coast, Northern Sierra, Centre Sierra, Southern Sierra, Forest, and Lima. We employ macroregions instead of individual geopolitical departments as it allows for including a larger number of sectoroccupation fixed effects. Otherwise, the small number of observations for a single department could comprise the estimation of the unexplained gaps (most likely underestimated) if certain sector-occupations regressors are not included due to a lack of degrees of freedom.

Panels $A$ and $B$ in Figure 4 show the average regional raw wage gap for the periods 2007-2010 and 2011-2018, respectively. We point at two findings. First, there is a considerable degree of heterogeneity across macroregions with the highest raw gaps surpassing $20 \%$. Remarkable examples are the Forest region with negative raw gaps during 2007-2010 and close to zero during 2011-2018. The Andean regions (mainly Southern and Centre Sierra) average a gender wage gap of over $20 \%$ during both periods. Second, there are no significant changes over time in terms of raw gap (See Table 6). Similarly, Panels $C$ and $D$ show the average unexplained wage gap for the corresponding periods. As in the case of the raw gap, the unexplained gap in Peru is heterogeneous across regions: It ranges from $12 \%$ in Lima to $27 \%$ in Centre Sierra, and it is always positive. By comparing two periods of analysis, we notice subtle differences, despite observing that most regions have reduced their average unexplained gap.

Table 5. Machado-Mata quantile decomposition.

\begin{tabular}{|c|c|c|c|c|c|}
\hline & p10 & p25 & p50 & p75 & p90 \\
\hline \multicolumn{6}{|c|}{ (A) Raw gap } \\
\hline 2007 & $\begin{array}{l}0.35^{* * * *} \\
(0.02)\end{array}$ & $\begin{array}{l}0.16 * * * \\
(0.02)\end{array}$ & $\begin{array}{c}0.04^{*} \\
(0.02)\end{array}$ & $\begin{array}{l}-0.09 * * * \\
(0.03)\end{array}$ & $\begin{array}{l}-0.09 * * * \\
(0.3)\end{array}$ \\
\hline 2011 & $\begin{array}{l}0.27^{* * *} \\
(0.03)\end{array}$ & $\begin{array}{l}0.18^{* * * *} \\
(0.02)\end{array}$ & $\begin{array}{l}0.10^{* * *} \\
(0.02)\end{array}$ & $\begin{array}{c}0.02 \\
(0.02)\end{array}$ & $\begin{array}{c}0.03 \\
(0.03)\end{array}$ \\
\hline 2018 & $\begin{array}{l}0.21^{* * * *} \\
(0.02)\end{array}$ & $\begin{array}{l}0.15^{* * * *} \\
(0.01)\end{array}$ & $\begin{array}{l}0.10 * * * \\
(0.01)\end{array}$ & $\begin{array}{c}0.04^{*} \\
(0.02)\end{array}$ & $\begin{array}{c}0.00 \\
(0.02)\end{array}$ \\
\hline \multicolumn{6}{|c|}{ (B) Unexplained gap } \\
\hline 2007 & $\begin{array}{l}0.39 * * * \\
(0.02)\end{array}$ & $\begin{array}{l}0.23^{* * *} \\
(0.02)\end{array}$ & $\begin{array}{l}0.16^{* * * *} \\
(0.02)\end{array}$ & $\begin{array}{l}0.06 * * * \\
(0.02)\end{array}$ & $\begin{array}{l}0.05^{* *} \\
(0.03)\end{array}$ \\
\hline 2011 & $\begin{array}{l}0.29 * * * \\
(0.03)\end{array}$ & $\begin{array}{l}0.21^{* * *} \\
(0.02)\end{array}$ & $\begin{array}{l}0.16^{* * *} \\
(0.02)\end{array}$ & $\begin{array}{l}0.12 * * * \\
(0.02)\end{array}$ & $\begin{array}{l}0.10^{* * *} \\
(0.03)\end{array}$ \\
\hline 2018 & $\begin{array}{l}0.18^{* * *} \\
(0.02)\end{array}$ & $\begin{array}{l}0.13^{* * *} \\
(0.01)\end{array}$ & $\begin{array}{l}0.13^{* * *} \\
(0.01)\end{array}$ & $\begin{array}{l}0.13^{* * *} \\
(0.02)\end{array}$ & $\begin{array}{l}0.08^{* * *} \\
(0.02)\end{array}$ \\
\hline
\end{tabular}

Notes: All decompositions include controls such as education, native tongue, age, tenure, private sector and firm size, occupation, economic activity, and regional fixed effects; repetition parameter in the MM is set to 100 ; robust standard errors in parenthesis; ${ }^{* * *} p<0.01$, $* * p<0.05, * p<0.10$. 
Panel A: Raw Gap for 2007-2010

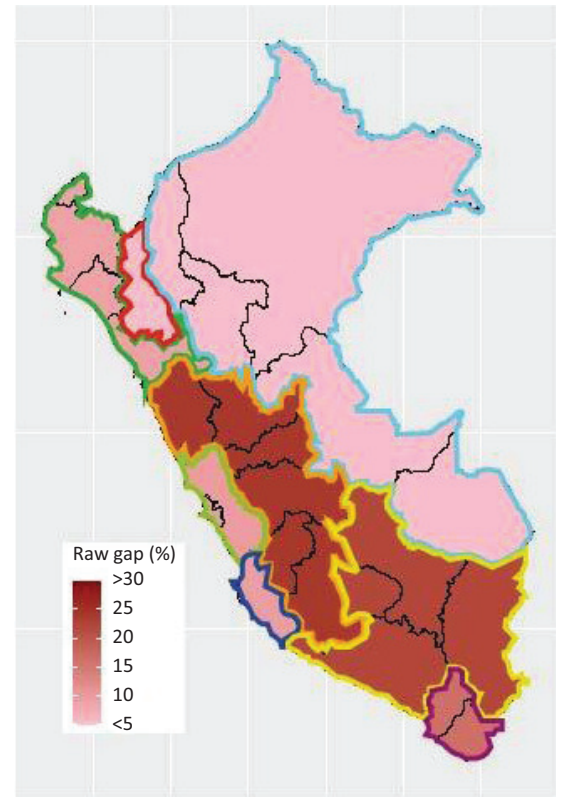

Panel C: Unexplained Gap for 2007-2010

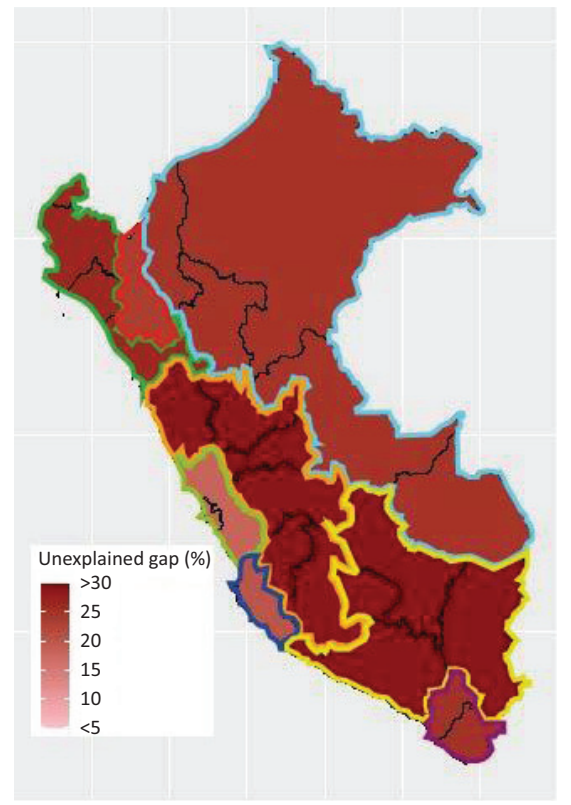

Panel B: Raw Gap for 2011-2018

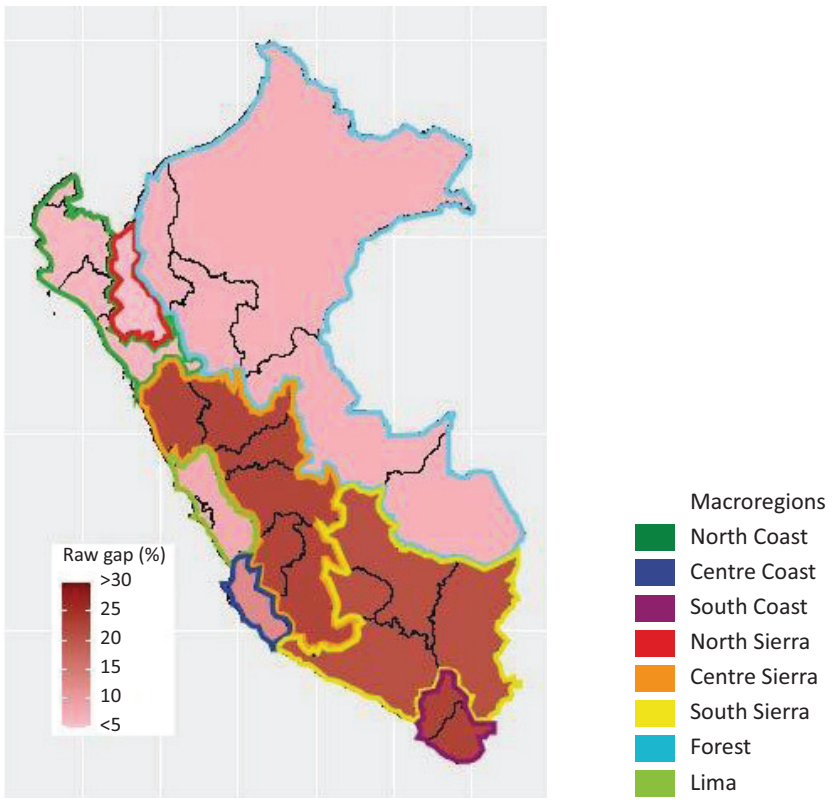

Panel D: Unexplained Gap for 2011-2018

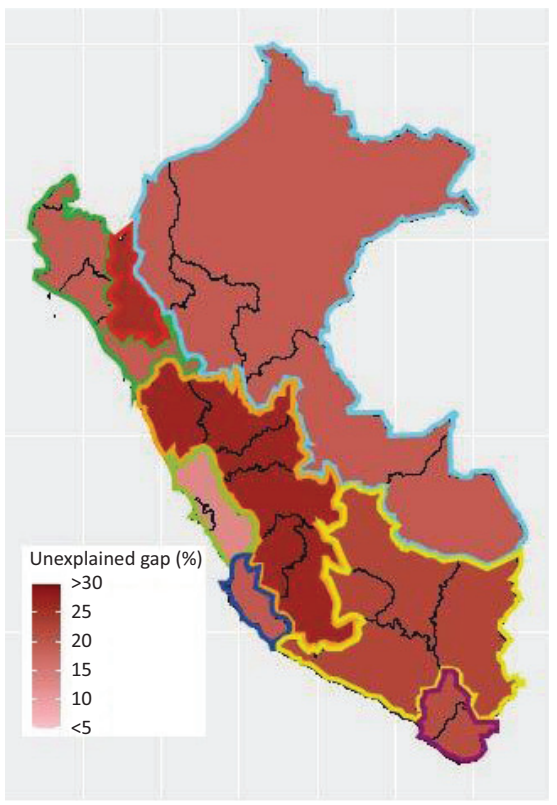

Figure 4. Average raw and unexplained wage gaps across macro regions. Notes: Raw gender gaps are computed using the In (hourly wage) separately for each macro region; data included has been weighted using sampling weights from the ENAHO survey; unexplained gaps are computed using the base O-B decomposition.

Following a similar procedure to Piazzalunga and $\mathrm{Di}$ Tommaso (2019), we statistically test whether overall regional gender gaps have changed significantly between the two periods of analysis. We found no statistical differences in the average raw wage gap for most regions (with the noticeable exception of Northern Sierra), as shown by Table 6 . We also decompose the changes in the raw gap into changes in the explained and unexplained components, which matches with the observed changes in Figure 4. As suggested previously, some of the regions show reductions in the unexplained wage gap over time (ranging from -8 p.p. to +3 p.p., widening the latter). Nonetheless, these regional changes in isolation may not account for a significant change in the national trend. Moreover, the reductions in the unexplained component are offset by an increase of the explained wage gap in every macro-region (ranging from +3 p.p. to +12 p.p.). These translate into a rather stable raw wage gap over time and across most macro-regions.

We also test for regional gap heterogeneities over the earnings distribution. For each macro-region, we perform the MM decomposition using the complete sample 
Table 6. Intertemporal wage gap decomposition, by macro-regions.

\begin{tabular}{|c|c|c|c|c|c|c|c|c|}
\hline & $\begin{array}{c}\text { Northern } \\
\text { Coast }\end{array}$ & $\begin{array}{c}\text { Centre } \\
\text { Coast }\end{array}$ & $\begin{array}{c}\text { Southern } \\
\text { Coast }\end{array}$ & $\begin{array}{c}\text { Northern } \\
\text { Sierra }\end{array}$ & $\begin{array}{l}\text { Centre } \\
\text { Sierra }\end{array}$ & $\begin{array}{c}\text { Southern } \\
\text { Sierra }\end{array}$ & Forest & Lima \\
\hline Raw gender gapp. 2011-2018 & $\begin{array}{l}0.06 * * * \\
(0.01)\end{array}$ & $\begin{array}{l}0.13^{* * *} \\
(0.01)\end{array}$ & $\begin{array}{l}0.23^{* * * *} \\
(0.02)\end{array}$ & $\begin{array}{c}0.02 \\
(0.03)\end{array}$ & $\begin{array}{l}0.23^{* * *} \\
(0.01)\end{array}$ & $\begin{array}{l}0.21 * * * \\
(0.01)\end{array}$ & $\begin{array}{l}0.07^{* * * *} \\
(0.01)\end{array}$ & $\begin{array}{l}0.08 * * * \\
(0.01)\end{array}$ \\
\hline Raw gender gapp. 2007-2010 & $\begin{array}{l}0.09 * * * \\
(0.02)\end{array}$ & $\begin{array}{l}0.10 * * * \\
(0.02)\end{array}$ & $\begin{array}{l}0.17^{* * *} \\
(0.03)\end{array}$ & $\begin{array}{l}-0.12 * * * \\
(0.05)\end{array}$ & $\begin{array}{l}0.25^{* * *} \\
(0.02)\end{array}$ & $\begin{array}{l}0.23^{* * *} \\
(0.03)\end{array}$ & $\begin{array}{c}0.05^{* *} \\
(0.02)\end{array}$ & $\begin{array}{l}0.10 * * * \\
(0.02)\end{array}$ \\
\hline Ch. in raw gender gap (pp.) & $\begin{array}{l}-0.03 \\
(0.02)\end{array}$ & $\begin{array}{c}0.03 \\
(0.02)\end{array}$ & $\begin{array}{c}0.07^{*} \\
(0.04)\end{array}$ & $\begin{array}{l}0.15^{* * *} \\
(0.05)\end{array}$ & $\begin{array}{l}-0.02 \\
(0.03)\end{array}$ & $\begin{array}{l}-0.01 \\
(0.03)\end{array}$ & $\begin{array}{c}0.03 \\
(0.02)\end{array}$ & $\begin{array}{l}-0.02 \\
(0.02)\end{array}$ \\
\hline Due to ch. in exp. gap (pp.) & $\begin{array}{c}0.03 \\
(0.02)\end{array}$ & $\begin{array}{c}0.03 \\
(0.02)\end{array}$ & $\begin{array}{c}0.07^{* *} \\
(0.03)\end{array}$ & $\begin{array}{c}0.12 * * \\
(0.05)\end{array}$ & $\begin{array}{c}0.04 \\
(0.02)\end{array}$ & $\begin{array}{l}0.07^{* * *} \\
(0.02)\end{array}$ & $\begin{array}{l}0.07^{* * *} \\
(0.02)\end{array}$ & $\begin{array}{l}0.03^{* * *} \\
(0.01)\end{array}$ \\
\hline Due to ch. in unex. gap (pp.) & $\begin{array}{l}-0.06^{* * *} \\
(0.02)\end{array}$ & $\begin{array}{c}0.00 \\
(0.02)\end{array}$ & $\begin{array}{l}-0.00 \\
(0.03)\end{array}$ & $\begin{array}{c}0.03 \\
(0.04)\end{array}$ & $\begin{array}{c}-0.05^{* *} \\
(0.02)\end{array}$ & $\begin{array}{l}-0.08^{* * *} \\
(0.02)\end{array}$ & $\begin{array}{c}-0.05^{*} \\
(0.02)\end{array}$ & $\begin{array}{c}-0.05 * * \\
(0.02)\end{array}$ \\
\hline
\end{tabular}

Notes: All decompositions are estimated separately for each macro region and include controls such as education, native tongue, age, tenure (in main occupation), private sector and firm size, as well as occupation, economic activity; robust standard errors in parenthesis; $* * * p<0.01, * * p<0.05, * p<0.10$.

(i.e., observations from 2007 to 2018) but controlling for the year of each survey wave and using real wages. Results are displayed in Figure 5. We highlight some noteworthy ones. First, we observe similar downward slope gaps for most regions, both in the raw and unexplained gender differentials. This finding is in line with our aggregate results, pointing out a consistent outcome:
Larger gaps are found within the poorest quantiles, independently of the geographic and cultural conditions. However, the magnitude of the gap varies greatly across regions. On the one hand, Andean territories show the largest gender wage gaps at the lowest percentiles, at around $50 \%$ (but interestingly, almost $0 \%$ at the highest percentiles). On the other end, coastal regions-
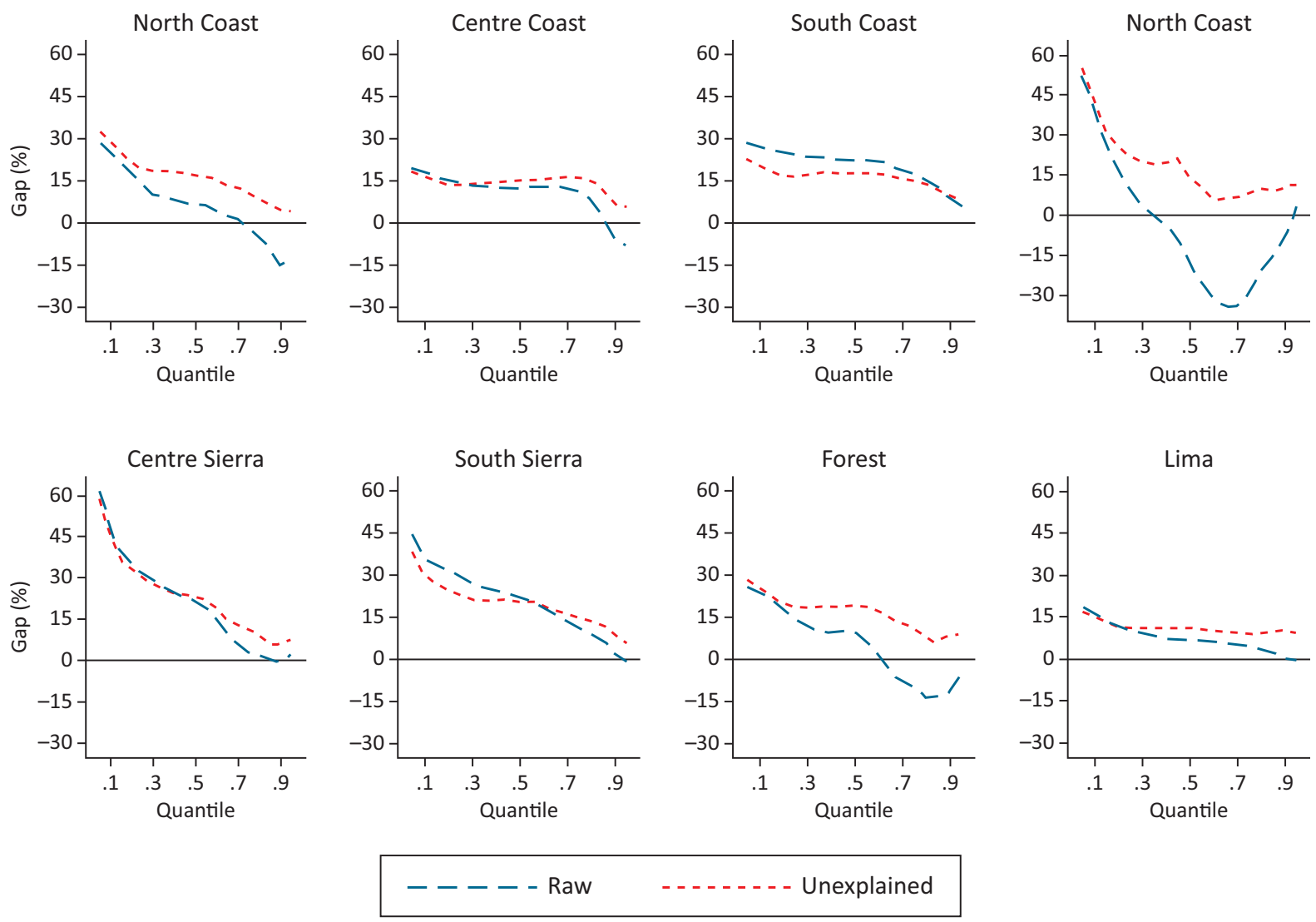

Figure 5. Regional Machado-Mata quantile decomposition. Notes: All decompositions include controls such as education, native tongue, age, tenure, private sector and firm size, occupation, economic activity, and regional fixed effects; the parameter in the MM is set to 100 . 
including the capital, Lima-are the ones with a less stepped slope, oscillating around a $20 \%$ average gap for most of the percentiles. Second, contrary to the national aggregate results, there are few regions (Southern Coast or the Southern Sierra) with raw gaps surpassing their unexplained gaps for some quantiles, revealing important regional differences in observable endowment. For these regions, the human capital endowment for working men is larger than for working women, suggesting these could be regions with stronger structural inequalities in other domains. Recent works such as Fuchs et al. (2021) argue that spatial differences in gender gaps may be related to heterogeneous regional contexts for men and women. These could be, for example, in terms of access to education (in all levels), the ability to engage in the labour market at an early age, and the possibility to participate in well-remunerated sectors. Altogether, these factors could be behind working men having more years of education and work experience for some particular regions. Hints of these structural differences could be seen when comparing urbanity, poverty rates, education and GDP across macro-regions, which are displayed in Table 7.

Afterwards, Table 8 shows the raw and unexplained gap at a region-year level and uses them as dependent variables to run a pooled regression against regional aggregate variables. The method of estimation does not intend to identify causal effects, but instead to shed some light on interesting associations that could help to better comprehend regional differences. The variables analysed were GDP per capita, population size, the macro-regional Gini Index, urbanity rate, the percentage of women who self-reported as household heads, poverty rate, informality rate and domestic physical violence rate towards women. This latter variable considers the proportion of women who suffered from kicking, dragging, strangling, burning and threatening or attacking with a weapon by their partner.

We highlight three main results. First, the GDP per capita consistently has a significant negative relationship with each of the gaps. This indicates that regions with more income and economic development have a lower gender wage gap. Table 7 displays an extreme exemplification of this relationship: the region with the highest GDP per capita, Lima, is the one with the smallest unexplained gap, while the one with the lowest GDP per capita, Centre Sierra, is actually the one with the largest unexplained component. These results are in line with Duflo (2012), who explains a strong and potentially bi-directional relationship between women's empowerment and economic development. Second, the gender physical violence rate widens the raw gap and

Table 7. Summary statistics by macro-regions.

\begin{tabular}{|c|c|c|c|c|c|c|c|c|}
\hline & $\begin{array}{c}\text { Northern } \\
\text { Coast }\end{array}$ & $\begin{array}{c}\text { Centre } \\
\text { Coast }\end{array}$ & $\begin{array}{c}\text { Southern } \\
\text { Coast }\end{array}$ & $\begin{array}{c}\text { Northern } \\
\text { Sierra }\end{array}$ & $\begin{array}{l}\text { Centre } \\
\text { Sierra }\end{array}$ & $\begin{array}{c}\text { Southern } \\
\text { Sierra }\end{array}$ & Forest & Lima \\
\hline GDP per capita (USD) & $\begin{array}{r}1020.17 \\
(40.50)\end{array}$ & $\begin{array}{l}2103.67 \\
(126.68)\end{array}$ & $\begin{array}{r}1973.49 \\
(33.77)\end{array}$ & $\begin{array}{l}873.95 \\
(36.22)\end{array}$ & $\begin{array}{l}879.61 \\
(28.11)\end{array}$ & $\begin{array}{r}1205.05 \\
(72.54)\end{array}$ & $\begin{array}{r}1010.30 \\
(30.34)\end{array}$ & $\begin{array}{l}3932.48 \\
(188.42)\end{array}$ \\
\hline Population (in millions) & $\begin{array}{c}2.58 \\
(0.04)\end{array}$ & $\begin{array}{c}1.20 \\
(0.02)\end{array}$ & $\begin{array}{c}0.38 \\
(0.01)\end{array}$ & $\begin{array}{c}1.02 \\
(0.01)\end{array}$ & $\begin{array}{c}2.03 \\
(0.03)\end{array}$ & $\begin{array}{c}2.37 \\
(0.05)\end{array}$ & $\begin{array}{c}2.14 \\
(0.03)\end{array}$ & $\begin{array}{c}5.99 \\
(0.12)\end{array}$ \\
\hline Gini Index & $\begin{array}{c}0.57 \\
(0.04)\end{array}$ & $\begin{array}{c}0.54 \\
(0.04)\end{array}$ & $\begin{array}{c}0.50 \\
(0.03)\end{array}$ & $\begin{array}{c}0.60 \\
(0.04)\end{array}$ & $\begin{array}{c}0.55 \\
(0.03)\end{array}$ & $\begin{array}{c}0.54 \\
(0.03)\end{array}$ & $\begin{array}{c}0.56 \\
(0.03)\end{array}$ & $\begin{array}{c}0.55 \\
(0.04)\end{array}$ \\
\hline Urbanity rate & $\begin{array}{c}0.88 \\
(0.01)\end{array}$ & $\begin{array}{c}0.91 \\
(0.01)\end{array}$ & $\begin{array}{c}0.92 \\
(0.01)\end{array}$ & $\begin{array}{c}0.36 \\
(0.02)\end{array}$ & $\begin{array}{c}0.62 \\
(0.02)\end{array}$ & $\begin{array}{c}0.70 \\
(0.02)\end{array}$ & $\begin{array}{c}0.64 \\
(0.02)\end{array}$ & $\begin{array}{c}1.00 \\
(0.00)\end{array}$ \\
\hline Men's years of education & $\begin{array}{c}9.80 \\
(0.17)\end{array}$ & $\begin{array}{l}10.73 \\
(0.15)\end{array}$ & $\begin{array}{l}11.00 \\
(0.29)\end{array}$ & $\begin{array}{c}7.27 \\
(0.22)\end{array}$ & $\begin{array}{c}9.28 \\
(0.23)\end{array}$ & $\begin{array}{l}10.33 \\
(0.21)\end{array}$ & $\begin{array}{c}8.68 \\
(0.18)\end{array}$ & $\begin{array}{l}11.63 \\
(0.13)\end{array}$ \\
\hline Women's years of education & $\begin{array}{c}9.11 \\
(0.25)\end{array}$ & $\begin{array}{l}10.09 \\
(0.30)\end{array}$ & $\begin{array}{c}9.98 \\
(0.32)\end{array}$ & $\begin{array}{c}5.56 \\
(0.32)\end{array}$ & $\begin{array}{c}7.40 \\
(0.35)\end{array}$ & $\begin{array}{c}8.46 \\
(0.28)\end{array}$ & $\begin{array}{c}7.49 \\
(0.22)\end{array}$ & $\begin{array}{l}10.10 \\
(0.25)\end{array}$ \\
\hline Poverty rate & $\begin{array}{c}0.25 \\
(0.09)\end{array}$ & $\begin{array}{c}0.13 \\
(0.06)\end{array}$ & $\begin{array}{c}0.14 \\
(0.06)\end{array}$ & $\begin{array}{c}0.55 \\
(0.08)\end{array}$ & $\begin{array}{c}0.36 \\
(0.11)\end{array}$ & $\begin{array}{c}0.28 \\
(0.10)\end{array}$ & $\begin{array}{c}0.33 \\
(0.12)\end{array}$ & $\begin{array}{c}0.14 \\
(0.06)\end{array}$ \\
\hline Gender physical violence rate & $\begin{array}{c}0.09 \\
(0.01)\end{array}$ & $\begin{array}{c}0.11 \\
(0.01)\end{array}$ & $\begin{array}{c}0.15 \\
(0.01)\end{array}$ & $\begin{array}{c}0.10 \\
(0.01)\end{array}$ & $\begin{array}{c}0.18 \\
(0.02)\end{array}$ & $\begin{array}{c}0.22 \\
(0.02)\end{array}$ & $\begin{array}{c}0.15 \\
(0.01)\end{array}$ & $\begin{array}{c}0.11 \\
(0.01)\end{array}$ \\
\hline Women as Household head & $\begin{array}{c}0.14 \\
(0.00)\end{array}$ & $\begin{array}{c}0.18 \\
(0.01)\end{array}$ & $\begin{array}{c}0.21 \\
(0.01)\end{array}$ & $\begin{array}{c}0.13 \\
(0.01)\end{array}$ & $\begin{array}{c}0.16 \\
(0.00)\end{array}$ & $\begin{array}{c}0.17 \\
(0.00)\end{array}$ & $\begin{array}{c}0.13 \\
(0.01)\end{array}$ & $\begin{array}{c}0.17 \\
(0.01)\end{array}$ \\
\hline Raw wage gap & $\begin{array}{c}0.08 \\
(0.05)\end{array}$ & $\begin{array}{c}0.13 \\
(0.03)\end{array}$ & $\begin{array}{c}0.22 \\
(0.06)\end{array}$ & $\begin{array}{c}-0.04 \\
(0.11)\end{array}$ & $\begin{array}{c}0.23 \\
(0.04)\end{array}$ & $\begin{array}{c}0.21 \\
(0.07)\end{array}$ & $\begin{array}{c}0.05 \\
(0.05)\end{array}$ & $\begin{array}{c}0.08 \\
(0.04)\end{array}$ \\
\hline Unexplained wage gap & $\begin{array}{c}0.21 \\
(0.05)\end{array}$ & $\begin{array}{c}0.19 \\
(0.02)\end{array}$ & $\begin{array}{c}0.22 \\
(0.05)\end{array}$ & $\begin{array}{c}0.22 \\
(0.07)\end{array}$ & $\begin{array}{c}0.29 \\
(0.04)\end{array}$ & $\begin{array}{c}0.24 \\
(0.05)\end{array}$ & $\begin{array}{c}0.21 \\
(0.04)\end{array}$ & $\begin{array}{c}0.14 \\
(0.04)\end{array}$ \\
\hline
\end{tabular}

Notes: Standard deviation in parenthesis; we use the exchange rate PEN to USD (on each survey year) to express the GDP per capita in USD. 
Table 8. Aggregate regional regressions.

\begin{tabular}{|c|c|c|c|c|}
\hline \multirow[b]{2}{*}{ GDP per capita (in logs) } & \multicolumn{2}{|c|}{ Raw gap (\%) } & \multicolumn{2}{|c|}{ Unexplained gap (\%) } \\
\hline & $\begin{array}{l}-0.112^{* * *} \\
(0.030)\end{array}$ & $\begin{array}{l}-0.117^{* * *} \\
(0.032)\end{array}$ & $\begin{array}{l}-0.069 * * * \\
(0.022)\end{array}$ & $\begin{array}{l}-0.089 * * * \\
(0.022)\end{array}$ \\
\hline Population (in logs) & $\begin{array}{c}0.014 \\
(0.011)\end{array}$ & $\begin{array}{c}0.021 \\
(0.020)\end{array}$ & $\begin{array}{c}-0.005 \\
(0.009)\end{array}$ & $\begin{array}{c}0.007 \\
(0.015)\end{array}$ \\
\hline Gini Index & $\begin{array}{c}-0.147 \\
(0.477)\end{array}$ & $\begin{array}{c}-0.009 \\
(0.562)\end{array}$ & $\begin{array}{c}0.043 \\
(0.354)\end{array}$ & $\begin{array}{c}0.068 \\
(0.382)\end{array}$ \\
\hline Poverty rate (\%) & $\begin{array}{l}-0.096 \\
(0.145)\end{array}$ & $\begin{array}{c}-0.042 \\
(0.178)\end{array}$ & $\begin{array}{l}0.222^{* *} \\
(0.108)\end{array}$ & $\begin{array}{c}0.166 \\
(0.143)\end{array}$ \\
\hline Gender physical violence rate (\%) & $\begin{array}{l}1.086^{* * *} \\
(0.139)\end{array}$ & $\begin{array}{l}1.031^{* * *} \\
(0.243)\end{array}$ & $\begin{array}{l}0.405^{* * *} \\
(0.105)\end{array}$ & $\begin{array}{c}0.233 \\
(0.167)\end{array}$ \\
\hline Urbanity rate (\%) & $\begin{array}{c}-0.127 \\
(0.100)\end{array}$ & $\begin{array}{c}-0.162 \\
(0.148)\end{array}$ & $\begin{array}{c}-0.127 \\
(0.082)\end{array}$ & $\begin{array}{c}-0.042 \\
(0.128)\end{array}$ \\
\hline Informality (\%) & $\begin{array}{c}-0.169 \\
(0.249)\end{array}$ & $\begin{array}{c}-0.102 \\
(0.327)\end{array}$ & $\begin{array}{c}-0.053 \\
(0.202)\end{array}$ & $\begin{array}{c}-0.134 \\
(0.249)\end{array}$ \\
\hline Women as Household Head (\%) & $\begin{array}{l}1.968^{* * *} \\
(0.463)\end{array}$ & $\begin{array}{l}2.547^{* * *} \\
(0.833)\end{array}$ & $\begin{array}{c}0.657^{*} \\
(0.346)\end{array}$ & $\begin{array}{l}1.303^{* *} \\
(0.602)\end{array}$ \\
\hline Observations & 88 & 88 & 88 & 88 \\
\hline R-squared & 0.734 & 0.756 & 0.530 & 0.604 \\
\hline Time Fixed Effects & No & Yes & No & Yes \\
\hline
\end{tabular}

Notes : Observations are set at a region-year level; robust standard errors in parenthesis; ${ }^{* * *} p<0.01,{ }^{* *} p<0.05,{ }^{*} p<0.10$.

unexplained wage gaps. This is a particularly relevant relationship to explore in Peru considering that seven out of ten women have experienced some type of violence by their current or prior partners, and recent evidence suggests that geographic conditions may be more relevant than individual characteristics at predicting gender violence (Hernández et al., 2018). As displayed by Table 7, Southern Sierra and the Centre Sierra are the regions with the highest gender physical violence rate, as well as the highest unexplained gaps. This might suggest that cultural practices are an important factor behind gender wage differences in the macroregions. There are two main mechanisms through which labour outcomes and domestic violence could be negatively associated. According to the theory of exposure, incrementing individual employment will reduce domestic violence by reducing the time partners spend together; and according to household bargaining theory, an increase in a woman's relative wage raises her power position and lowers the levels of violence in the household (Aizer, 2010; Zhang \& Breunig, 2021). However, the backlash effect posits a positive relationship between gender physical violence and labour outcomes (Hornung et al., 1981; Macmillan \& Gartner, 1999). Our estimates are in line with the household bargaining model. Finally, we document the significant and positive association between the presence of Women as Heads of the Household and gender wage gaps. In principle, it could be logical to expect a negative relationship, considering being a household head could be read as having a stronger power position with respect to her partner.
However, in Peru, $65.8 \%$ of the households with women as the breadwinners are single-parent ones (INEI, 2017), therefore it would be hard to argue that being a household head necessarily translates into a better bargaining position within the household. Moreover, this last result may suggest that those regions where women struggle more greatly to support their families are those where women may be forced to allocate in less favourable jobs and sectors (due to time constraints for example), facing larger wage gaps.

\section{Conclusion}

This study provides a comprehensive review of the evolution of the Peruvian gender wage gaps and identifies key variables that explain observable differences. Despite recent social advances and economic growth, Peru is still one of the countries with the highest gender inequality in the region, mainly in terms of economic independence and labour participation (WEF, 2020). This is particularly worrying if we acknowledge the pervasive effect of current social issues, such as teenage pregnancy and gender violence, in shaping the role of Peruvian women in the economy.

The main findings of this study suggest that the Peruvian unexplained gap has remained stable during the last 13 years at around $17 \%$, with only minor reductions at the lowest end of the wage distribution. During this period, the unexplained wage gap has been consistently larger than the observable raw gap, which provides evidence that human capital variables may act as 
mechanisms for narrowing observable gender wage differentials. However, the fact that the unexplained wage gap has remained virtually unchanged suggests the presence of structural problems concerning social norms, gender stereotyping and potentially discrimination in the Peruvian Market that needs to be addressed. A derived policy implication is the need for changing gender stereotypes especially related to who should be the primary caregiver in a household. In addition, the creation of a national care system that allows households to access subsidised or free day care for children under three years old.

In addition, we conclude that education keeps playing an equalising role: education in the unexplained and explained component contributes to reducing the observable gap of working men and women. Results from the Heckman adjusted decomposition suggest that only the more educated women are taking part in the labour market. In this sense, efforts to narrow education gaps could help to mitigate the gender wage differences by tackling systematic factors that hinder the transition of women into the labour market, especially of those less educated. Our results point out that women at the lowest end of the earnings distribution are most likely to change their employment status and enter into the labour market. Our quantile analysis shows that the incidence of the unexplained gaps is considerably higher for the poorest, which may actually act as disincentives for employment participation if economic payoffs for women in these jobs are too low. This leads to a pervasive cycle of human capital losses for women, which reinforces wage and participation gaps.

Finally, we provide evidence that the most vulnerable workers are consistently exposed to a higher unexplained wage difference. This includes those positioned at the lowest end of the income distribution, informal workers, and the least educated. Finally, after computing the raw and unexplained gap at a region-year level, we show a great degree of heterogeneity both at the observable and unexplained gaps, but also some common trends such as downward slope wage gaps across the distributions and always-positive unexplained gaps. Moreover, we show that the regional GDP per capita is negatively associated with both gender wage gaps, while the domestic gender physical violence rate and the percentage of women as household heads hold a positive relation.

\section{Conflict of Interests}

The authors declare no conflict of interest.

\section{References}

Aizer, A. (2010). The gender wage gap and domestic violence. American Economic Review, 100(4), 1847-1859.

Albrecht, J., Van Vuuren, A., \& Vroman, S. (2009). Coun- terfactual distributions with sample selection adjustments: Econometric theory and an application to the Netherlands. Labour Economics, 16(4), 383-396.

Antón, J. I., \& Muñoz de Bustillo, R. (2015). Public-private sector wage differentials in Spain: An updated picture in the midst of the Great Recession. Investigación Económica, 74(292), 115-157.

Atal, J., Ñopo, N. H., \& Winder, N. (2009). New century, old disparities. Gender and ethnic wage gaps in Latin America (IDB Working Paper IDB-WP-109). Inter-American Development Bank.

Badel, A., \& Peña, X. (2010). Decomposing the gender wage gap with sample selection adjustment: Evidence from Colombia (CEDE Document 2010-37). Universidad de los Andes.

Barrantes, R., \& Matos Trifu, P. (2019). "En capilla": Desigualdades en la inserción laboral de mujeres jóvenes ["In chapel": Inequalities in the employment of young women]. Instituto de Estudios Peruanos.

Beltrán, A., Sanborn, C., \& Yamada Fukusaki, G. (2021). En búsqueda de un desarrollo integral: 20 ensayos en torno al Perú del Bicentenario [In search of integral development: 20 essays on Peru's Bicentennial]. Universidad del Pacífico.

Blau, F. D., \& Beller, A. H. (1988). Trends in earnings differentials by gender, 1971-1981. Industrial and Labor Relations Review, 41(4), 513-529.

Blinder, A. S. (1973). Wage discrimination: Reduced form and structural estimates. Journal of Human Resources, 8(4), 436-455.

Boraz, F., \& Robano, C. (2010). Brecha salarial en Uruguay [Gender wage gap in Uruguay]. Revista de Análisis Económico, 25(1), 49-77.

Carrillo, P., Gandelman, N., \& Robano, V. (2014). Sticky floors and glass ceilings in Latin America. Journal of Economic Inequality, 12(3), 339-361.

Castillo, L. E. (2020). Regional dynamics of income inequality in Peru (Report No. 2020-004). Banco Central de Reserva del Perú.

Chernozhukov, V., Fernández-Val, I., \& Melly, B. (2013). Inference on counterfactual distributions. Econometrica, 81(6), 2205-2268.

Christofides, L. N., Polycarpou, A., \& Vrachimis, K. (2013). Gender wage gaps, "sticky floors" and "glass ceilings" in Europe. Labour Economics, 21, 86-102.

Chzhen, Y., \& Mumford, K. (2011). Gender gaps across the earnings distribution for full-time employees in Britain: Allowing for sample selection. Labour Economics, 18(6), 837-844.

Del Pozo Segura, J. M. (2017). Has the gender wage gap been reduced during the "Peruvian growth miracle?" A distributional approach (Report No. 2017-442). Departamento de Economía, Pontificia Universidad Católica del Perú.

Duflo, E. (2012). Women empowerment and economic development. Journal of Economic Literature, 50(4), 1051-1079.

Fortin, N. M. (2008). The gender wage gap among young 
adults in the United States the importance of money versus people. Journal of Human Resources, 43(4), 884-918.

Fuchs, M., Rossen, A., Weyh, A., \& Wydra-Somaggio, G. (2021). Where do women earn more than men? Explaining regional differences in the gender pay gap. Journal of Regional Science, 61(5), 1065-1086. https://doi.org/10.1111/jors.12532

González, P., Santos, M. C., \& Santos, L. D. (2005). The gender wage gap in Portugal: Recent evolution and decomposition (CETE Discussion Paper no. 505). Universidade do Porto, Faculdade de Economia do Porto

Heckman, J. J. (1979). Sample selection bias as a specification error. Econometrica, 47(1), 153-161.

Hernández, W., Raguz, M., Morales, H., \& Burga, A. (2018). Feminicidio: Determinantes y evaluación del riesgo [Femicide: Determinants and risk assessment]. Consorcio de Investigación Económica y Social Lima.

Hornung, C. A., McCullough, B. C., \& Sugimoto, T. (1981). Status relationships in marriage: Risk factors in spouse abuse. Journal of Marriage and the Family, 43(3), 675-692.

Hughes, J., \& Maurer-Fazio, M. (2002). Effects of marriage, education and occupation on the female/male wage gap in China. Pacific Economic Review, 7(1), 137-156.

INEI. (2016). Clasificador nacional de ocupaciones 2015: Basado en la clasificación internacional uniforme de ocupaciones 2008 elaborado por la Organización Internacional del Trabajo [National occupation classification 2015: Based on the 2008 international and homogeneous occupation classification developed by the International Labour Organization].

INEI. (2017). Perú: Perfil sociodemográfico informe nacional [Peru: Sociodemographic profile national report]. Censos Nacionales 2017: XII de población, VII de vivienda y III de comunidades indígenas [National census 2017: XII population, VII households, and III indigenous communities].

INEI. (2019). Perú: Evolución de Indicadores de empleo e ingreso por departamento 2007-2018 [Peru: Evolution of employment and income indicators by department 2007-2018].

International Monetary Fund. (2020). World economic outlook: A long and difficult ascent.

Machado, J. A., \& Mata, J. (2005). Counterfactual decomposition of changes in wage distributions using quantile regression. Journal of Applied Econometrics, 20(4), 445-465.

Macmillan, R., \& Gartner, R. (1999). When she brings home the bacon: Labor-force participation and the risk of spousal violence against women. Journal of Marriage and the Family, 61(4), 947-958.

MTPE. (2006). La mujer en el mercado laboral peruano [Women in the Peruvian labour market]. Ministerio de Trabajo y Promoción del Empleo.

Neumark, D., \& Vaccaro, G. (2020). The career evolution of the sex gap in wages: Discrimination vs. human capital investment (Report No. w28191). National Bureau of Economic Research.

Ñopo, H. (2009). The gender wage gap in Peru 1986-2000: Evidence from a matching comparisons approach (Working Paper No. 675). Inter-American Development Bank

Oaxaca, R. (1973). Male-female wage differentials in urban labor markets. International Economic Review, 14(3), 693-709.

Piazzalunga, D., \& Di Tommaso, M. L. (2019). The increase of the gender wage gap in Italy during the 2008-2012 economic crisis. The Journal of Economic Inequality, 17(2), 171-193.

Seminario, B., Zegarra, M. A., \& Palomino, L. (2019). Estimación del PIB departamental y análisis de la desigualdad regional en el Perú: 1795-2017 [Departmental GDP estimate and regional inequality analysis in Peru: 1795-2017] (Working Paper No. 1016). InterAmerican Development Bank.

Shi, L., Jin, S., \& Xiaochuan, L. (2011). Evolution of the gender wage gap among China's urban employees. Social Sciences in China, 32(3), 161-180.

Vargas, S. (2014). Bajo el radar de Sofía. Oportunidades y barreras de las profesionales en el Perú [Under Sofia's radar. Opportunities and barriers for professionals in Peru]. Instituto de Estudios Peruanos Lima.

WEF. (2020). Global gender gap report. Geneva.

Zhang, Y., \& Breunig, R. V. (2021). Gender norms and domestic abuse: Evidence from Australia (Working Paper No. 5). Tax and Transfer Policy Institute.

\section{About the Authors}

Giannina Vaccaro is a senior economist and researcher, currently a member of the Swiss Centre of Expertise in the Social Sciences (FORS) and the Institute of Social Sciences (ISS) at the University of Lausanne, and affiliated with the Competence Centre for Diversity and Inclusion (CCDI) at the University of St. Gallen, in Switzerland. She has broad international experience and her scientific work focuses on applied microeconomics topics related to labour, education, and gender economics. She is an expert in policy evaluation and econometric analysis. Her research interests extend also to questions related to retirement, health, urban economics, and economics of development.

Maria Pia Basurto is a researcher and full-time professor in the Economics Department at Universidad del Pacífico, Lima, Peru. She holds a PhD and an MA in economics from the University of California, Santa Cruz, USA. Her research interests are development economics and its intersection with the economics of education, gender, public policies, and impact evaluation. Besides academic professional experience, she has worked for the public sector. 


\section{COGITATIO}

Arlette Beltrán is vice president for research and full professor in the Department of Economics at Universidad del Pacífico. She holds a PhD in economics from Pontificia Universidad Católica del Perú and a Master of Arts in economics from Georgetown University. Her research interests are social policies, economic and social gender gaps, and participatory budgeting with a gender perspective. She has developed several investigations associated with the quantitative analysis of aspects related to the coverage and quality of educational and health services.

Mariano Montoya is an applied economist with a research interest in development economics. He has worked as a research assistant in the Economics Department of Universidad del Pacífico, as well as for the Ministry of Economics and Finance of Peru. At the moment of publication, he is currently doing an M.Sc. in economics at KU Leuven (Belgium) and holds a B.Sc. in economics at Universidad del Pacífico (Peru). 